\title{
Original Paper \\ Quararibea bovinii (Malvaceae), a new species from the Brazilian Atlantic Forest
}

\author{
Carlos Daniel Miranda Ferreira ${ }^{1,2,3}$
}

\begin{abstract}
In the present study, I propose a new species, Quararibea bovinii, an Atlantic Forest tree. The new taxon occurs in southeastern Brazil, in the states of Espírito Santo, Rio de Janeiro, and São Paulo. It resembles $Q$. similis in terms of floral morphology and fruit shape, but it is distinguished by the indumenta of leaves, leaf width, and seed shape.

Key words: bifurcated trichome, conservation, domatia, Matisieae, taxonomy.

\section{Resumo}

Quararibea bovinii é proposta como uma nova espécie para a Mata Atlântica. Sua distribuição é restrita ao sudeste do Brasil, ocorrendo nos estados do Espírito Santo, Rio de Janeiro e São Paulo. É semelhante a $Q$. similis em relação à morfologia das flores e forma dos frutos, mas se distingue pelo indumento das folhas, a largura das folhas e a forma das sementes.

Palavras-chave: tricoma bifurcado, conservação, domácia, Matisieae, taxonomia.
\end{abstract}

\section{Introduction}

Quararibea Aublet (1775: 692) is a genus of Malvaceae comprising at least 44 species broadly distributed in the Neotropics from Mexico to Brazil and Bolivia (Pittier 1945; Alverson 1986; Fernandez-Alonso 1999, 2001a, b, 2002; Zamora et al. 2017; Cascante-Marín et al. 2018; Ferreira et al. 2018). This genus is characterized by small to medium-sized trees with simple leaves, flowers ranging from 2 to $23.5 \mathrm{~cm}$ in length, half-inferior ovaries, staminal tubes that are slightly lobed apically, anthers with completely fused filaments, and fleshy indehiscent drupes (Pittier 1945; Alverson 1986, 1989; Bayer \& Kubitzki 2003; Ferreira et al. 2018).

The analyzes by Alverson et al. (1999) and Baum et al. (2004) support the positioning of Quararibea in the Matisieae clade, together with two other genera, Phragmotheca Cuatr. and Matisia Humb. \& Bonpl. These molecular phylogenies place tribe Matisieae in subfamily Malvoideae, which is plausible because of their highly fused staminal filaments, monothecate anthers, tubular calyces, and apparently simple leaves, however none of which are a unique synapomorphy of Malvoideae (Alverson et al. 1999).

In Brazil, there are eleven species recorded in northern, northeastern, midwestern, and southeastern regions of the country (Flora do Brasil 2020; Ferreira et al. 2018). According to Ferreira $\&$ Bovini (2020), there are five Quararibea species in the southeastern Brazilian Atlantic Forest: $Q$. angustifolia (Martius 1839: 17) C.D.M. Ferreira \& Bovini (2018: 1013), Q. bragae C.D.M. Ferreira \& Bovini (2020: 225), Q. penduliflora (Saint-Hilaire 1825: 269) Schumann (1886: 241), Q. similis C.D.M. Ferreira \& Bovini (2018: 1016), and $Q$. turbinata (Swartz 1788: 102) Poiret (1816: 636).

After a careful revision of specimens from Brazilian herbaria and collections of specimens in situ, I observed differences in the morphology of the specimens from the states of Espírito Santo, Rio de Janeiro, and São Paulo, recognized here as $Q$. bovinii.

\footnotetext{
${ }^{1}$ Escola Nacional de Botânica Tropical, Instituto de Pesquisas Jardim Botânico do Rio de Janeiro, Jardim Botânico, Rio de Janeiro, RJ, Brazil.

${ }^{2}$ ORCID: <https://orcid.org/0000-0001-6583-8750>.

${ }^{3}$ Author for correspondence: cdmferreira.quararibea@gmail.com
} 


\section{Materials and Methods}

The present study involved bibliographic search and analysis of herbarium specimens, including $\mathrm{BHCB}, \mathrm{C}$, ESA, GUA, HB, K, MBML, R, RB, RBR, RFFP, SP, SPF, UEC, and VIES (acronyms follow Thiers, continuously updated), to obtain data about their geographic distribution and morphology. I also carried out field expeditions to the states of Espírito Santo, Rio de Janeiro, and São Paulo to update distribution, morphology, and habitat data. I deposited the specimens collected in the herbarium of the Rio de Janeiro Botanical Garden Research Institute (RB). I used leaf samples removed from vouchers RB159179 and RB338616 for scanning electron microscopy (SEM) analyses. All samples were fixed with carbon adhesive tape on stubs and coated with a thin gold layer of approximately $20 \mathrm{~nm}$ (Emitech K550X Sputter Coater) and observed under a scanning electron microscope (EVO 40, Zeiss) at a voltage of $15 \mathrm{kV}$. The description of trichome morphology followed Payne (1978) and Theobald et al. (1979), and for the domatia adopted the terminology of O'Dowd \& Wilson (1989). Additionally, I determined the conservation status of this new species following IUCN guidelines (2019).

\section{Results and Discussion}

Quararibea bovinii C.D.M. Ferreira, sp. nov.

Figs. 1; 2

Similar to Quararibea similis C.D.M. Ferreira \& Bovini, but differing in the width of the leaves $[(3.8-) 6.2-13.3(-16) \times 4.1-7.2(-10)]$, the indumentum of the leaves, comprised of simple, bifurcate and fasciculate trichomes (vs. glabrous or fasciculate and/or dentate-lepidote trichomes), the presence of hair-tuft domatia ( $v s$. the absence of domatia) and obovoid or rarely fusiform seeds (vs. fusiform to oblong).

Type: BRAZIL. RIO DE JANEIRO: Jacarepaguá, Parque Estadual da Pedra Branca, 22 56'17'S, 4327'46”'W, 518 m, 10.IV.2016, C.D.M. Ferreira \& T.B.S. Patusco 288 (Holotype: RB!, Isotypes: CEPEC!, MG!, NY!).

Small trees 3-8 m tall. Young branches covered with fasciculate brownish trichomes. Petioles ca. 0.9-1.2(-1.6) cm long, densely covered with fasciculate brownish trichomes; stipules densely covered with dentate-lepidote trichomes. Leaves (8.5-)14.1-24.4(-32.1) $\times$ (3.8-)6.2-13.3(-16) cm., membranaceous, usually asymmetric, obovate to elliptic, margins entire, apex acuminate, base usually rounded, sometimes subcordate, asymmetric; midvein of adaxial surface with simple, bifurcate and fasciculate hyaline trichomes, abaxial surface covered with simple, bifurcate and fasciculate hyaline trichomes and bearing hair-tuft domatia (rarely absent), which consist of simple, bifurcate and fasciculate trichomes in the axillary midveins. Flowers solitary, opposite the leaves, sometimes ramiflorous, erect; pedicels $0.6-1.2(-1.7) \mathrm{cm}$ long, densely covered with dentate-lepidote, hyaline trichomes and micro-trichomes, bearing three triangular, marcescent bracteoles with obtuse apices, the bracteoles densely covered with dentate-lepidote, browinish micro-trichomes; calyces $0.6-1.2 \times 0.4-0.5 \mathrm{~cm}, 2-5$ lobate, the lobes triangular and cuneate-inflexed at their apices, densely covered with dentate-lepidote brownish trichomes and micro-trichomes; petals ca. $1.4 \times$ $0.2 \mathrm{~cm}$, narrowly spatulate, bearing fasciculate and dentate-lepidote, hyaline trichomes and micro-trichomes on both sides; staminal columns 0.9-1.7 cm long, 5-toothed at apex, covered with densely fasciculate, hyaline trichomes, glabrate; ovaries pilose, covered with stellate-porrect, hyaline trichomes; styles frequently exceeding the staminal columns by ca. $1 \mathrm{~mm}$, covered with stellate-porrect, hyaline trichomes; stigmas capitate, white. Fruits turbinate, ca. $3.3 \times 0.6-1.6$ $\mathrm{cm}, 1-2$ seeded, the apices covered by dentatelepidote micro-trichomes, the bases acute and surrounded by the accrescent calyces; seeds planoconvex or rounded, obovoid, rarely fusiform, ca. $1.2 \times 0.5-0.8 \mathrm{~cm}$.

Selected examined material: BRAZIL. ESPÍRITO SANTO: Atílio Vivacqua, Moitão, 19.I.2008, fl. and fr., L. Kollmann et al. 10329 (MBML, RB). RIO DE JANEIRO: Angra dos Reis, Parque Estadual de Cunhambebe, 16.III.2013, fl., A.A.M. de Barros et al. 4848 (RFFP). Casimiro de Abreu, Reserva Biológica União, 7.IV.2012, fl., E.A. Ribeiro 286 (RFFP). Caxias, Reserva da Petrobras, $22^{\circ} 33^{\prime}$ 'S, $43^{\circ} 16^{\prime}$ 'W, 6.V.1997, fl. and. fr., J.M.A. Braga et al. 4010 (RB). Magé, $\mathrm{III}^{\circ}$ Distrito, Paraiso, Centro de Primatologia do RJ, 4.XII.1984, G. Martinelli \& S. Pessoa 10463 (RB). Mangaratiba, Rio das Pedras, 18.I.2001, fl., M.G. Bovini et al. 1962 (RB). Paraty, Laranjeiras, APA-Cairuçu, 29.III.1995, fl., L.C. Giordano et al. 1869 (RB). Petrópolis, estrada Rio-Petrópolis, XI.1938, fl., $H$. Monteiro 1933 (RB). Rio das Ostras, Reserva Biológica União, 11.III.1999, fl., P.P. Oliveira 903H (BHCB). Rio de Janeiro, Parque Estadual da Pedra Branca, Jacarepaguá, 22 $56^{\prime} 17^{\prime \prime}$ 'S, 4327'46”W, 19.III.2016, fl., C.D.M. Ferreira \& P. Feliz 265 (RB); III.1872, fl., A. Glaziou 2934 (C, K). SÃO PAULO: Iguape, 


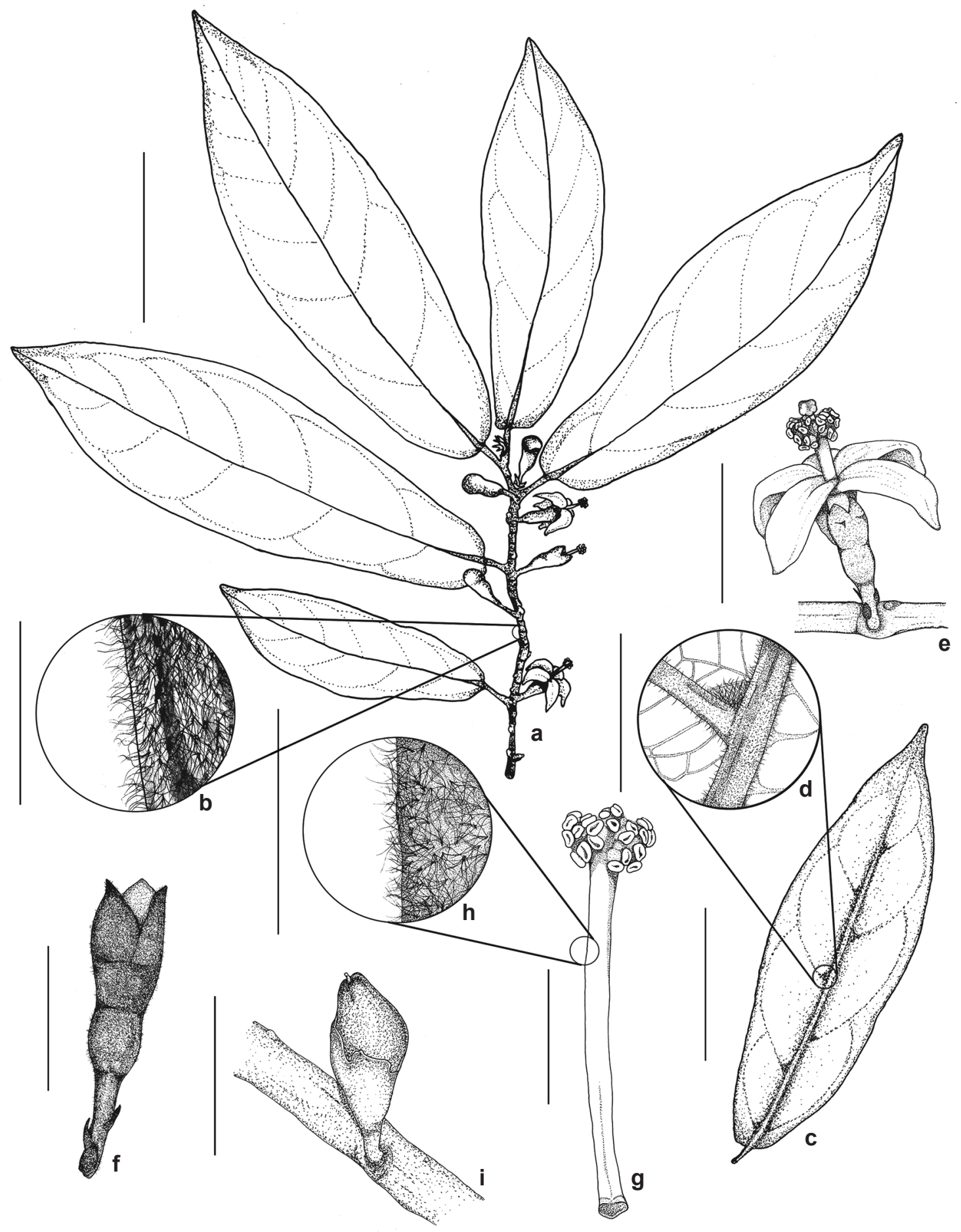

Figure 1 - a-i. Quararibea bovinii - a. floriferous branch; b. detail of branch indumentum; c. leaf (abaxial face); d. detail of hair-tuft domatia; e. flower; f. calyx; g. staminal column; h. detail of staminal column indumentum; i. immature fruit. Drawing by Thayane Patusco, based on C.D.M. Ferreira \& T.B.S. Patusco 288 (a-d. dry material; e-i. fresh material). Scale bar: a, c = $5 \mathrm{~cm}$; e, i = $2 \mathrm{~cm}$; b, d, h=1 mm; f, g = $5 \mathrm{~mm}$. 
Estação Ecológica Juréia-Itatins, Serra da Juréia, trilha do Imperador em direção à Praia da Juréia, 10.I.1995, fl., A Rapini et al. 15 (SP, SPSF). Peruíbe, Estação Ecológica Júreia-Itatins, Núcleo Guarau, 27.I.2000, fl., I. Cordeiro et al. 2000 (SP). São Vicente, Parque Estadual Xixová-Japuí, 19.I.2001, fl., J.A. Postore \& C. Moura 935 (SP, SPSF). Ubatuba, Picinguaba, 26.III.1996, fl., A. Takahasi 259 (SP).

Quararibea bovinii is characterized by membranaceous leaves with hair-tuft domatia composed of simple, bifurcate and fasciculate trichomes on the abaxial surface between midribs and the secondary veins (Fig. 3). The presence of bifurcated trichomes and hair tuft domatia are considered diagnostic characteristics, allowing the identification of the taxa even when sterile, as none of the other species occurring in southeastern Brazil show them.

Quararibea bovinii occurs in the states of Espírito Santo, Rio de Janeiro, and São Paulo (Fig. 4), in shaded and humid habitats, predominantly
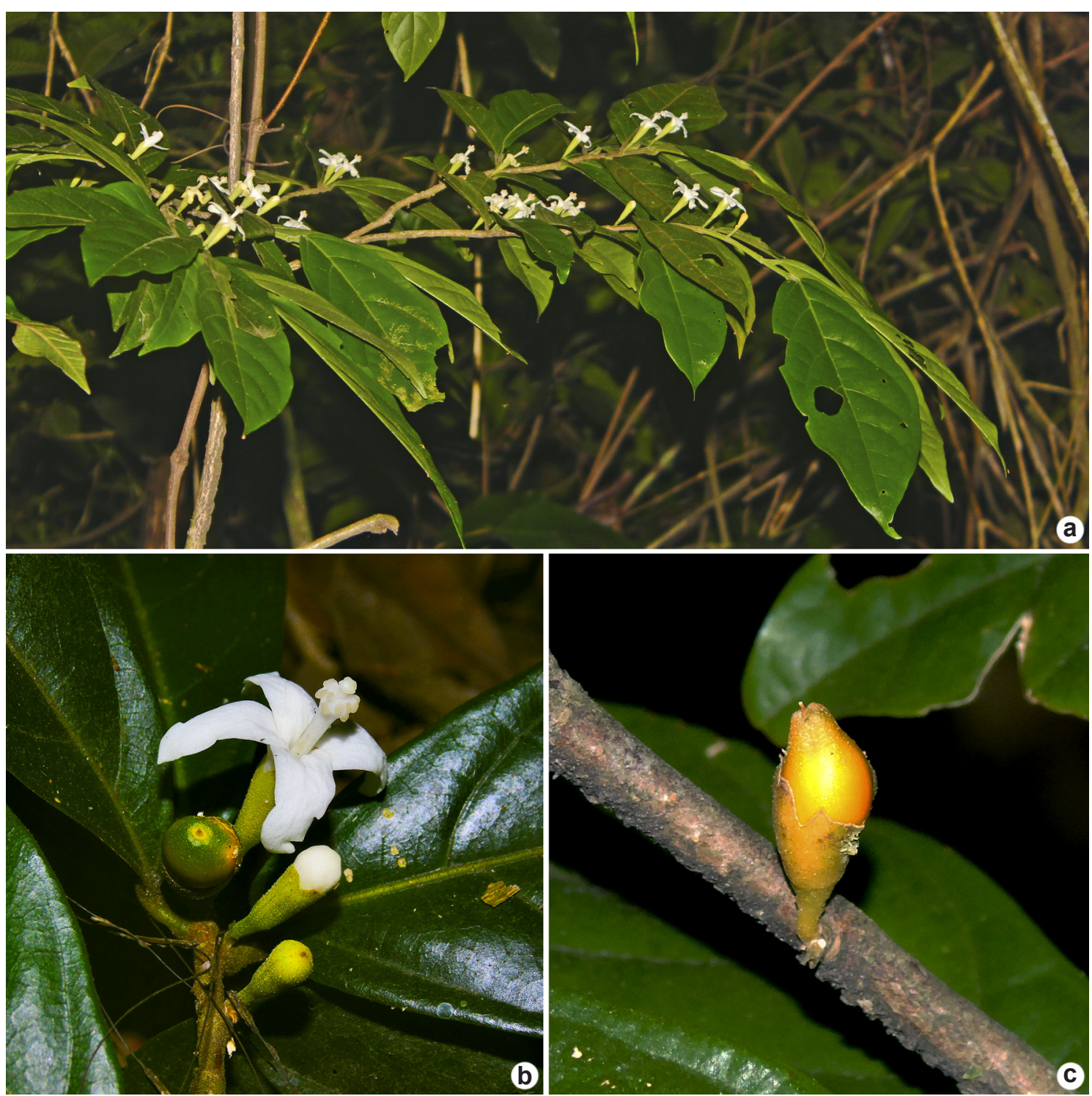

Figure 2 - a-c. Quararibea bovinii in the field - a. floriferous branch; b. flower, floral bud and immature fruit; c. mature fruit. Photos C.D.M. Ferreira. 
in rainforest areas with second-growth vegetation. It is found on the coast, at low elevations, ranging from $50-700 \mathrm{~m}$ a.s.1. and forms an aggregate distribution pattern. This species occurs over a vast area of the Atlantic Forest, with EOO surpassing $30,000 \mathrm{~km}^{2}$ and AOO surpassing 4,000 $\mathrm{km}^{2}$. In addition, most populations occur within reserves, such as Área de Proteção Ambiental de Mangaratiba, Estação Ecológica de JuréiaItatins, Parque Estadual da Pedra Branca, Parque
Estadual Cunhambebe, Parque Estadual dos Três Picos, Parque Estadual da Serra do Mar, Parque Estadual Xixová-Japuí, Reserva Biológica União, and Reserva da Petrobras. Therefore, in a formal assessment, $Q$. bovinii would most likely be considered a least concern species (LC) (IUCN 2019).

Quararibea bovinii flowers from November to May, showing nocturnal-crepuscular anthesis, and set fruits from May to September.
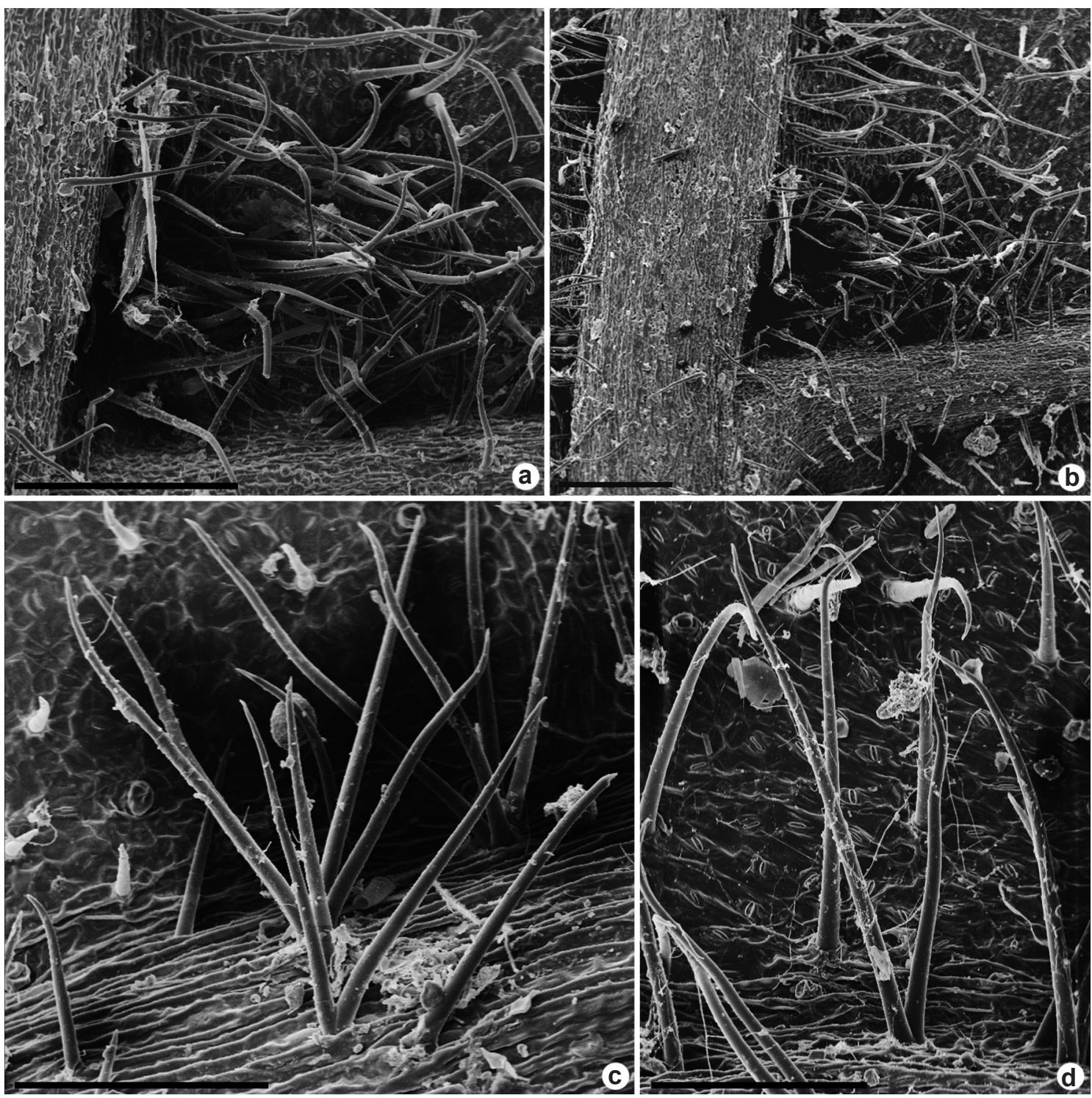

Figure 3 - a-d. Leaf (abaxial) surface of Quararibea bovinii - a, b. hair-tuft domatia; c, d. simple, bifurcate and fasciculated trichomes. Scale bar: a, $b=400 \mu \mathrm{m} ; \mathrm{c}, \mathrm{d}=200 \mu \mathrm{m}$. 
The epithet bovinii was named in honor of Ph.D. Massimo Giuseppe Bovini, one of the most significant contributors to the studies of
Malvaceae in Brazil. He also collected part of the materials examined for the description of this new taxon.

\section{Key to species of Quararibea from the Atlantic Forest of Brazil}

1. Abaxial surface of leaves with pocket domatia with simple trichomes only; flowers pendant; fruits oblong to obovoid or subglobose

1'. Abaxial surface of leaves with hair-tuft domatia with simple, bifurcate and fasciculate trichomes, or domatia absent; flowers erect; fruits oval to elliptic or turbinate

2. Leaves with fasciculate trichomes, abaxial surface with domatia in the primary, secondary, tertiary, and rarely in quaternary veins axils; staminal columns cylindrical-thoothed at apex, columns glabrous; fruits oblong to obovoid Quararibea bragae

2'. Leaves with dentate-lepidote trichomes, rarely glabrous on the adaxial face, abaxial face with domatia only in primary veins; staminal columns cylindrical-undulate at apex, columns with dentate-lepidote trichomes; fruits subglobose

3. Pedicels $0.4-1.1 \mathrm{~cm}$ long; calyces $1.1 \times 0.5 \mathrm{~cm}$; petals $1.4-1.7 \times 0.3-0.4 \mathrm{~cm}$; staminal columns ca. $1.8 \mathrm{~cm}$ long; fruits 2 -seeded Quararibea turbinata

3'. Pedicels (1.3-)2.5-3.6(-4.3) cm long; calyces $1.5-1.6 \times 0.6-0.7 \mathrm{~cm}$; petals ca. $2.9 \times 0.5 \mathrm{~cm}$; staminal columns $2.4-2.9 \mathrm{~cm}$ long; fruits $2-3$-seeded

4. Leaves lanceolate; pedicels ca. $0.6 \mathrm{~cm}$ long; fruits oval to elliptic Quararibea penduliflora

Quararibea angustifolia

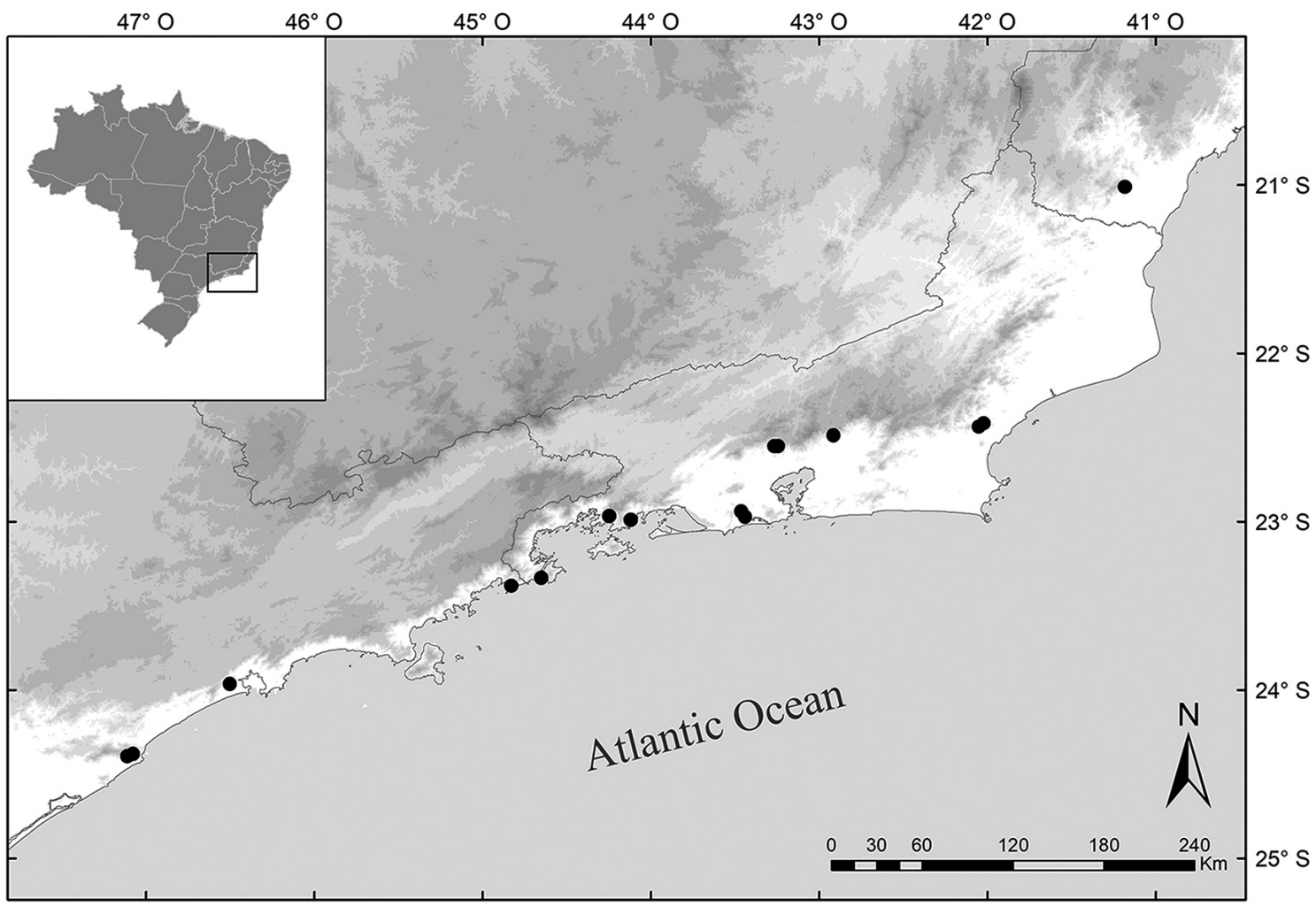

Figure 4 - Geographical distribution of Quararibea bovinii (circle). 
4'. Leaves elliptic to obovate; pedicels $0.6-1.9 \mathrm{~cm}$ long; fruits turbinate

5. Petioles with dentate-lepidote trichomes; adaxial surface of leaves with fasciculate and/or dentatelepidote trichomes in the midvein, or glabrate, abaxial surface with dentate-lepidote trichomes in the primary and secondary veins, domatia absent Quararibea similis

5'. Petioles with fasciculate trichomes; adaxial surface of leaves with simple, bifurcate and fasciculate trichomes on the midvein, abaxial surface with simple, bifurcate and fasciculate trichomes, hairtuft domatia present with simple, bifurcate and fasciculate trichomes Quararibea bovinii

\section{Acknowledgments}

I am grateful to the Laboratory of Structural Botany and in particular Ph.D. Karen De Toni, for the support during the production of images with scanning electron microscopy. I thank Thayane Patusco, for the beautiful illustrations that compose the present study. I also thank Pablo Fernando Feliz and André Luís Diniz Ferreira, for their help during fieldwork; and Rafael Almeida, for the initial review of English.

This study was financed in part by the Coordenação de Aperfeiçoamento de Pessoal de Nível Superior - Brasil (CAPES) - Finance Code 001.

\section{References}

Alverson WS (1986) Quararibea Aubl. sl (Bombacaceae) in Mexico, Central America and the Antilles: a taxonomic study. Doctor thesis. University of Wisconsin, Madison. 464p.

Alverson WS (1989) Matisia and Quararibea (Bombacaceae) should be retained as separate genera. Taxon 38: 377-388.

Alverson WS, Whitlock BA, Nyffeler R, Bayer C \& Baum DA (1999) Phylogeny of the core Malvales: evidence from $n d h F$ sequence data. American Journal of Botany 86: 1474-1486.

Aublet JBCF (1775) Quararibea. Histoire des Plantes de la Guiane Françoise 2: 691-694.

Baum DA, Smith SD, Yen A, Alverson WS, Nyffeler R, Whitlock BA \& Oldham RL (2004) Phylogenetic relationships of Malvatheca (Bombacoideae and Malvoideae; Malvaceae sensu lato) as inferred from plastid DNA sequences. American Journal of Botany 91: 1863-1871.

Bayer C \& Kubitzki K (2003) Malvaceae. In: Bayer C \& Kubitzki K (eds.) Flowering plants Dicotyledons. Springer, Berlin. Pp. 225-311.

Cascante-Marín A, Sánchez-González J \& Alverson WS (2018) A New Quararibea (Malvaceae) from the Caribbean Lowlands of Costa Rica. Novon 26: 262-267.

Fernández-Alonso JL (1999) Nueva especie y notas del género Quararibea (Bombacaceae). Revista de la Academia Colombiana de Ciencias Exactas, Físicas y Naturales 23 (Suplemento especial): 49-52.

Fernández-Alonso JL (2001a) Bombacaceae neotropicae novae vel minus cognitae I. Novedades taxonómicas y corológicas em Matisia, Quararibea y Spirotheca. Revista de la Academia Colombiana de Ciencias Exactas, Físicas y Naturales 25: 183-206.

Fernández-Alonso JL (2001b) Bombacaceae neotropicae novae vel minus cognitae - II. Novedades taxonómicas y corológicas en Matisia y Quararibea del norte de Sudamérica. Caldasia 23: 351-382.

Fernández-Alonso JL (2002) Bombacaceae neotropicae novae vel minus cognitae III. Nuevas especies de Matisia y Quararibea de Colombia. Novon 12: 343-351.

Ferreira CDM, Bovini MG \& De Toni KL (2018) Miscellaneous additions to Quararibea (Malvaceae) from Atlantic Forest of Southeast Brazil. Systematic Botany 43: 1011-1019.

Ferreira CDM \& Bovini MG (2020) Quararibea bragae (Malvaceae; Malvoideae): a new species with multiple domatia from Brazil. Phytotaxa: 224-230.

Flora do Brasil 2020 [constantly updated] Flora do Brasil 2020. Instituto de Pesquisas Jardim Botânico do Rio de Janeiro. Available at $<$ http://floradobrasil.jbrj.gov. br/>. Access on 25 December 2020.

IUCN [2019] Guidelines for using the IUCN Red List Categories and Criteria, version 14. Cambrigde. Available at $<$ http://www.iucnredlist.org/documents/ RedListGuidelines.pdf $>$. Access on 11 March 2020.

Martius CFP (1839) Herbarium florae brasiliensis. Flora 22: $17-20$.

O'dowd DJ \& Willson MF (1989) Leaf domatia and mites on Australasian plants: ecological and evolutionary implications. Biological Journal of the Linnean Society 37 : 191-238.

Payne WW (1978) A glossary of plant hair terminology. Brittonia 30: 239-255.

Pittier H (1945) Notas dendrológicas de Venezuela. Boletin de la Sociedad Venezolana de Ciencias Naturales 10: 107-115.

Poiret JLM (1816) Encyclopédie méthodique. Botanique. Supplement. Agasse, Paris 4: 636.

Saint-Hilaire A (1825) Myrodia. Flora Brasiliae Meridionalis 1: 268-271.

Schumann K (1886) Bombacaceae. In: Martius CFP \& Eichler AG (eds.) Flora Brasiliensis. Lipsiae: Frid. Fleischer, Munich. Vol. 12, pars 3, pp. 240-244. 
Swartz OP (1788) Nova genera \& species plantarum seu prodromus descriptionum vegetalium, maximam partem incognitorum quæ sub itinere in Indiam occidentalem annis. Uppsala and Abo, Stockholm. $152 \mathrm{p}$.

Theobald WL, Krahulik JL \& Rollins RC (1979) Trichome description and classification. In: Metcalfe CR \& Chalk L (eds.) Anatomy of the dicotyledons. Vol. I. Clarendon Press, Oxford. Pp. 40-53.
Thiers B [continuously updated] Index Herbariorum: a global directory of public herbaria and associated staff. New York Botanical Garden's Virtual Herbarium. Available at <http://sweetgum.nybg.org/ science/ih/>. Access on 1 October 2018.

Zamora NA, Cascante-Marín A, Choi S \& Kim SY (2017) A new species of Quararibea (Malvaceae) from Costa Rica. Phytoneuron 67: 1-6. 